$6-19-73$

193

\title{
THERMAL ANNEALING OF IRRADIATED LIH
}

\author{
H. R. Leider \\ V. Teas \\ C. M. Griffith
}

April 12, 1973

Prepared for U.S. Atomic. Energy Commission under contract No. W-7405-Eng-48
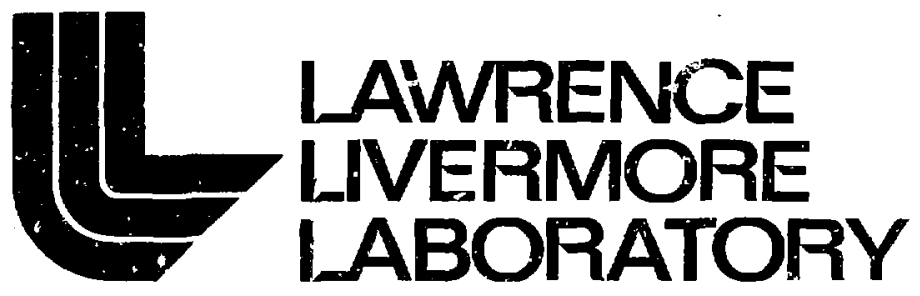

University of California/Livermore

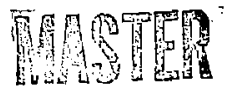




\section{NOTICE}

"This report was prepared as in account of work. iponsored by tho United States Government. Neither the Unites States nor the United States Atomle Energy Commission, nor any of their omployess, nor any of their contractors, subcontractoss, or their employass, makes any warranty, express or implled, c; assumes any legal Hobility or responsibility for the accuracy, completensss or usefulness of any information, apparatus, prorluct or process disclosed, or represents that its use would not infringe prjvatelyowned rights,"

Printed in the United States of America Avallable fros..

National Technical Information Service

U.S. Department of Commerce 5285 Port Royal Road Springfield, Virginia 22151

Price: Printed Copy \$ $\$$; ; Microfiche $\$ 0.95$

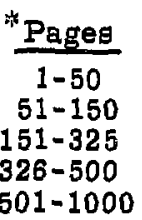

NTIS Selling Price

$\$ 4.00$

$\$ 5.45$

$\$ 7.60$

$\$ 10.60$

$\$ 13.60$ 
TID-4500, UC-4

Chemistry

\title{
迆 \\ LAWRENCE LNERMORE LABOFATORY

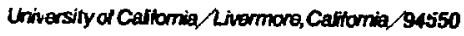

UCRL-51375

\section{THERMAL ANNEALING OF IRRADIATED LIH}

\author{
H. R. Leider \\ V. Teas \\ C. M. Griffith
}

MS. date: April 12, 1973

Thls report was prepared as an account of work
sponsored by the United States Government. Neither
the United States nor the United States Atumic Energy
Commission, nor any of their employees, nor any of
their contractors, subcontractors, os theis employees,
makes any warranty, express ar implied, or assumes any
legal liability or responslbility for the accuracy, com-
pletelless or usefuness of any information, apparatus,
product or oroce ss disclosed, or represents that its use
would not infringe privately owred tights. 


\title{
THERMAL ANNEALING OF IRRADIATED LiH
}

\author{
Abstract \\ The effects of tisermal annealing of \\ irradiated Lif on density, bubble size, \\ and bubble size distribution are pre- \\ sented for materials subjected to a wide \\ range of irradiation conditions.

Heating of irradiated LiH is known to cause back-reaction of the free hydrogen and lithium present ${ }^{1,2}$ as well as to produce changes in density. ${ }^{3}$ A correlation was previously made between the Limetal $/ \mathrm{H}_{2}$-gas ratio and the change in density after armealing. ${ }^{3}$ It $w$ as found that when this ratio was small, i. e., most of the expected metallic lithium was undetected by pulsed nuclear magnetic resonance (NMR), the material recovered much of the swelling produced by irradiation. Several annealed samples were examined by electron microscopy, and it was observed that fairly small changes in bubbile size resulted. These findiags were cited to support the conclusion that the back-reaction mechanism does not involve migration of bubbles. 2 The present re:sults show that, in general, bubble sizes increase substantially under some annealing conditions and, therefore, the back-reaction model must be re-examined.

A miscellany of annealing results are presented here, partly simply to record the experiments. Differential thermal analysis (DTA) showed that the back reaction of lithium and hydrogen in irradiated LiH becomes rapid between 350 and $450^{\circ} \mathrm{C}$. Most of the anneali $\mathrm{E}$ studies wers done on samples in which the back-reaction was completed. Some anneals had been attempted at lower temperati:es, particularly around $200^{\circ} \mathrm{C}$ where the "missing" lithium metal (to NMR) was known to precipitate. ${ }^{1}$ Very little change in density or internal decomposition was found in samples annealed between 200 and $250^{\circ} \mathrm{C}$ even fur heating times as long as 20 hours. No electron microscopy was done at or on these samples. Consequently, subsequent thermal annealing was done at or atove $400^{\circ} \mathrm{C}$ where the back-reaction occurs rapidly. Three different moiles of annealing were used, all of which are illustrated in Fig. 1. These are:

1. "Fast" heatin $n_{z}$ designated as F. An encapsulated sample was immersed in a furnace at $400^{\circ} \mathrm{C}$ and held there for times ranging from $5 \mathrm{~min}$ to $1 \mathrm{hr}$. Backreaction was always complete after $5 \mathrm{~min}$, and time at $400^{\circ} \mathrm{C}$ did not seem to change 

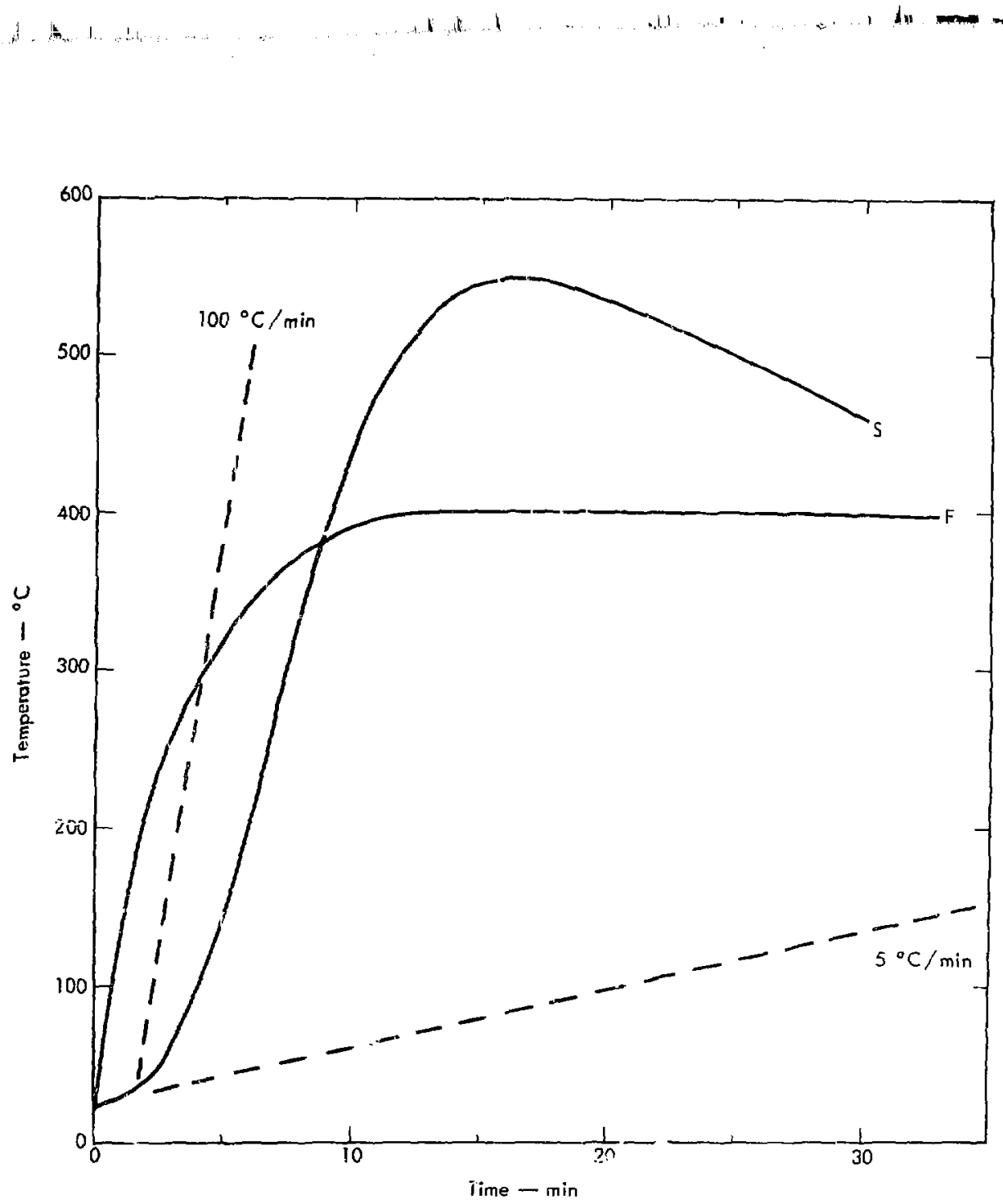

Fig. 1. T'emperature-time curves for the various thermai annealing conditions.

the properties. The initial heating rate was $>100^{\circ} \mathrm{C} / \mathrm{min}$.

2. "Slow" heating, designated as $\mathrm{S}$. In this procedure, the sealed sample was placed in the cold furnace, then the power was applied at a setting predetermined to hold $400^{\circ} \mathrm{C}$. However, the temperature overshoots to about $550^{\circ} \mathrm{C}$ before controlling at $400^{\circ} \mathrm{C}$.
3. Constant heating rate to $450^{\circ} \mathrm{C}$. The DTA apparatus ${ }^{1}$ was used to heat a small crystal at rates of $5^{\circ} \mathrm{C} / \mathrm{min}$, $20^{\circ} \mathrm{C} / \mathrm{inin}, 50^{\circ} \mathrm{C} / \mathrm{min}$, or $100^{\circ} \mathrm{C} / \mathrm{min}$. Power was turned off at $\sim 500^{\circ} \mathrm{C}$, and the system was cooled to near room temperature, usually in $20 \mathrm{~min}$. The DTA system heated at a constant rate only after a relatively slow initial climb 
to about $50^{\circ} \mathrm{C}$. The time vs temperature curves for the various annealing conditions are shown in Fig. 1.
The results from the annealing experiments are listed in Table 1 . Bubble sizes were determined by replication electron

Table 1. A summary of annealing data.

\begin{tabular}{|c|c|c|c|c|c|c|c|}
\hline Sample & $\begin{array}{l}\mathrm{T}_{\text {IRR }} \\
\left({ }^{\circ} \mathrm{C}\right)\end{array}$ & $\begin{array}{l}\text { Dose } \\
\text { (Grad) }\end{array}$ & Annealing procedure & $\overline{\mathrm{r}}{ }_{\mathrm{IRR}}^{\left(\mathrm{A}^{\prime} ;\right.}$ & $\overline{\mathbf{r}}_{\mathrm{ANN}}(\stackrel{\mathrm{A}}{ })$ & $\left(\frac{\Delta V}{V_{0}}\right)_{\text {IRR }}$ & $\left(\frac{\Delta V}{V_{0}}\right)_{A N N}$ \\
\hline $\mathrm{B} 7-1$ & 90 & 0.9 & $\mathrm{~F}, \mathrm{~S}$, and $50^{\circ} \mathrm{C} / \mathrm{min}$ & - & - & 0.015 & 0 \\
\hline \multirow[t]{3}{*}{ B7-3 } & 120 & 1.20 & $\mathbf{F}$ & 80 & 355 & .046 & 0.024 \\
\hline & & & $100^{\circ} \mathrm{C} / \mathrm{min}$ & 80 & 1820 & .046 & - \\
\hline & & & $50^{\circ} \mathrm{C} / \mathrm{min}$ & 80 & 1030 & .046 & $\cdots$ \\
\hline \multirow{5}{*}{$\mathrm{B} 7-2$} & 171 & 1.30 & $100^{\circ} \mathrm{C} /$ rnin & 250 & 1880 & .064 & .260 \\
\hline & & & $50^{\circ} \mathrm{C} / \mathrm{min}$ & 250 & 1900 & .064 & .057 \\
\hline & & & $20^{\circ} \mathrm{C} / \mathrm{min}$ & 250 & 2040 & .064 & .062 \\
\hline & & & $5^{\circ} \mathrm{C} / \mathrm{min}$ & 250 & 2420 & .064 & .043 \\
\hline & & & $S$ & 250 & 3230 & .064 & .074 \\
\hline \multirow[t]{5}{*}{ B7-4 } & 190 & 1.31 & $F$ & 395 & 660 & .065 & .678 \\
\hline & & & $100^{\circ} \mathrm{C} / \mathrm{mill}$ & 395 & 3630 & .065 & .056 \\
\hline & & & $50^{\circ} \mathrm{C} / \mathrm{min}$ & 395 & 1720 & .065 & .073 \\
\hline & & & $20^{\circ} \mathrm{C} / \mathrm{min}$ & 395 & 2010 & .065 & .038 \\
\hline & & & $\mathrm{E}^{\circ} \mathrm{C} / \mathrm{min}$ & 395 & 2750 & $.0 \hat{5} 5$ & .065 \\
\hline B7-5 & 220 & 1.33 & $\mathbf{S}$ & 570 & 2760 & .072 & .085 \\
\hline B12-1 & 76 & 5.5 & $\mathbf{S}$ & - & 2120 & .080 & .037 \\
\hline B12-3 & 130 & 6.6 & $\mathrm{~S}$ & 205 & 2800 & .097 & .096 \\
\hline B12-2 & 140 & 7.0 & $S$ & 245 & 3850 & .114 & .101 \\
\hline B12-4 & 203 & 7.2 & $F$ & 485 & 890 & .154 & .162 \\
\hline B12-5 & 207 & 7.2 & $\mathbf{F}$ & 500 & 970 & .160 & .162 \\
\hline B3-3 & 265 & 25.8 & $\mathbf{F}$ & 1450 & 1340 & .062 & .043 \\
\hline B5-3 & 215 & 3.2 & $s$ & 640 & 4830 & .116 & $.1 \% 7$ \\
\hline$B 5-2$ & 220 & 3.5 & $\mathbf{s}$ & 690 & 3850 & .129 & - \\
\hline B5-4 & 267 & 3.6 & $S$ & 1485 & 2570 & .104 &.$i 11$ \\
\hline B8-5 & 215 & 0.5 & $\mathbf{S}$ & 340 & 3550 & .018 & .025 \\
\hline B3-2 & 200 & 22.1 & $\mathrm{~F}$ & 725 & - & .249 & .188 \\
\hline B5-5 & 265 & 3.6 & $F$ & 1430 & - & .112 & .104 \\
\hline $\mathrm{B1}-1$ & 42 & 36.1 & $F$ & - & - & .166 & .122 \\
\hline$B 1-3$ & 85 & 45.4 & $\mathbf{F}$ & - & - & .166 & .122 \\
\hline
\end{tabular}


Table 1 (continued).

\begin{tabular}{|c|c|c|c|c|c|c|c|}
\hline Sample & $\begin{array}{l}{ }^{\mathrm{T}} \text { IRR } \\
\left({ }^{\circ} \mathrm{C}\right)\end{array}$ & $\begin{array}{l}\text { Dose } \\
\text { (Grad) }\end{array}$ & Annealing procedure & $\bar{r}_{\operatorname{IRR}(\stackrel{\AA}{A})}$ & $\overline{\mathrm{r}}_{\mathrm{ANN}}(\stackrel{\AA}{\mathrm{A}})$ & $\left(\frac{\Delta V}{V_{0}}\right)_{I R R}$ & $\left(\frac{\Delta V}{V_{C}}\right)_{\text {ANN }}$ \\
\hline $\mathrm{B} 2-1$ & 50 & 11.1 & $F$ & - & - & .091 & .051 \\
\hline$B 2-3$ & 100 & 13.9 & $F$ & - & - & .127 & .094 \\
\hline$B 2-4$ & 160 & 14.4 & $F$ & - & - & .216 & .200 \\
\hline$B 2-5$ & 195 & 13.2 & $F$ & - & - & 0.223 & 0.203 \\
\hline B5 -1 & 120 & 2.7 & $\mathrm{~F}$ & - & - & 0.070 & 0.041 \\
\hline B8-1 & 87 & 0.4 & $\mathrm{~F}$ & - & - & .008 & 0 \\
\hline $38-3$ & 116 & 0.5 & $\mathrm{~F}$ & - & - & .011 & 0 \\
\hline $\mathrm{B} 8-2$ & 161 & 0.5 & $\mathrm{~F}$ & - & - & 0.015 & 0.011 \\
\hline
\end{tabular}

microscopy, 4,5 and density was measured by flotation ${ }^{3}$ or with a gas comparison pycnometer ${ }^{6}$ when big enough samples were available. It was not always possible to measure bubble size because of the poor physical condition of some irradiated samples. A cleavable crystal chip is needed to prepare a replica and often the irradiated LiH was shattere': into yery small fragments.

Figure 2 is a photograph of a replica of one sample (B7-5) annealed by Procedure $S$, that is representative of the pictures used to measure bubble size. The range of bubble sicies here is $1000-10,000 \AA$. The relationship between swelling recovery after annealing and irradiation temperature is shown in Fig. 3. In general, it is found that samples irradiated below $170^{\circ} \mathrm{C}$ always recover some of the volume increase caused by irradiation. Three poinis are seen where all of the swelling disappeared. In these cases, the irradiation temperature was fairly low and the irradiation dose was less than 1 Grad. No correlation was seen with the irradia- tion dose, the amount of swelling from irradiation, or the annealing procedure.

Examination of Table 1 shows that large increases in bubble size results for materials annealed at constant heating rat? or $S$, whereas reiatively small changes are found for Condition F. Since the original procedure used was $F$, the interpretation of the back-reaction process excluded the possibility of bubble coalescence, ${ }^{2}$ as mentioned above. Possibly the determining factor in whether large changes in bubble size occur or not is the time in a small (but undefined) temperature interval.

Examination of Fig. 1 suggests that either this temperature interval is $\approx 200^{\circ} \mathrm{C}$ or that the differences may be due to the fact that temperature never exceeded $400^{\circ} \mathrm{C}$ for $\mathrm{F}$. If the latter is the case, then for some samples, bubble growth occurs after the back-reaction is complete, and the proposed mechunism ${ }^{2}$ is not invalidated. Lack of samples and time have prevented a systematic investigation.

An interesting trend is shown in Fig. 4 where the bubbla concentration is plotted 


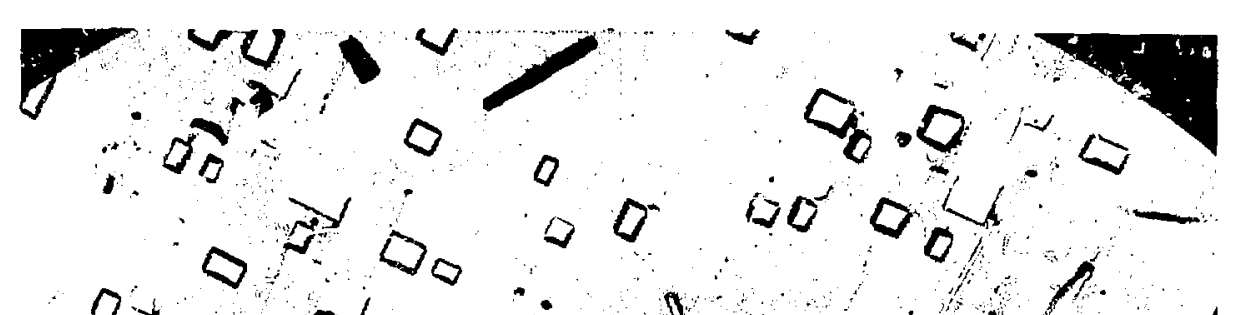

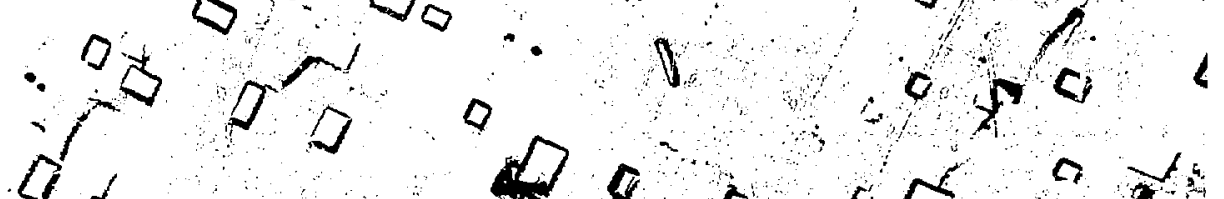

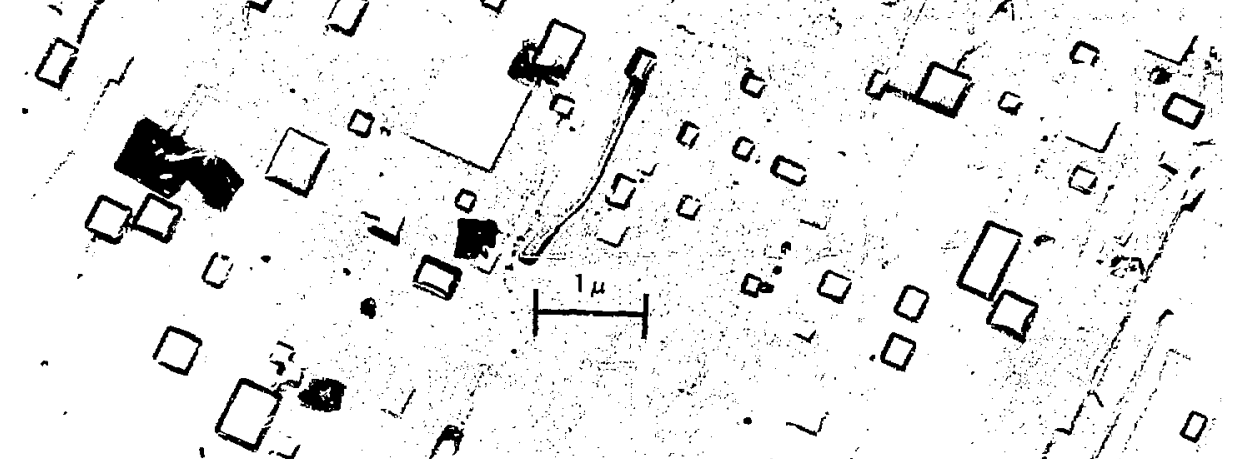

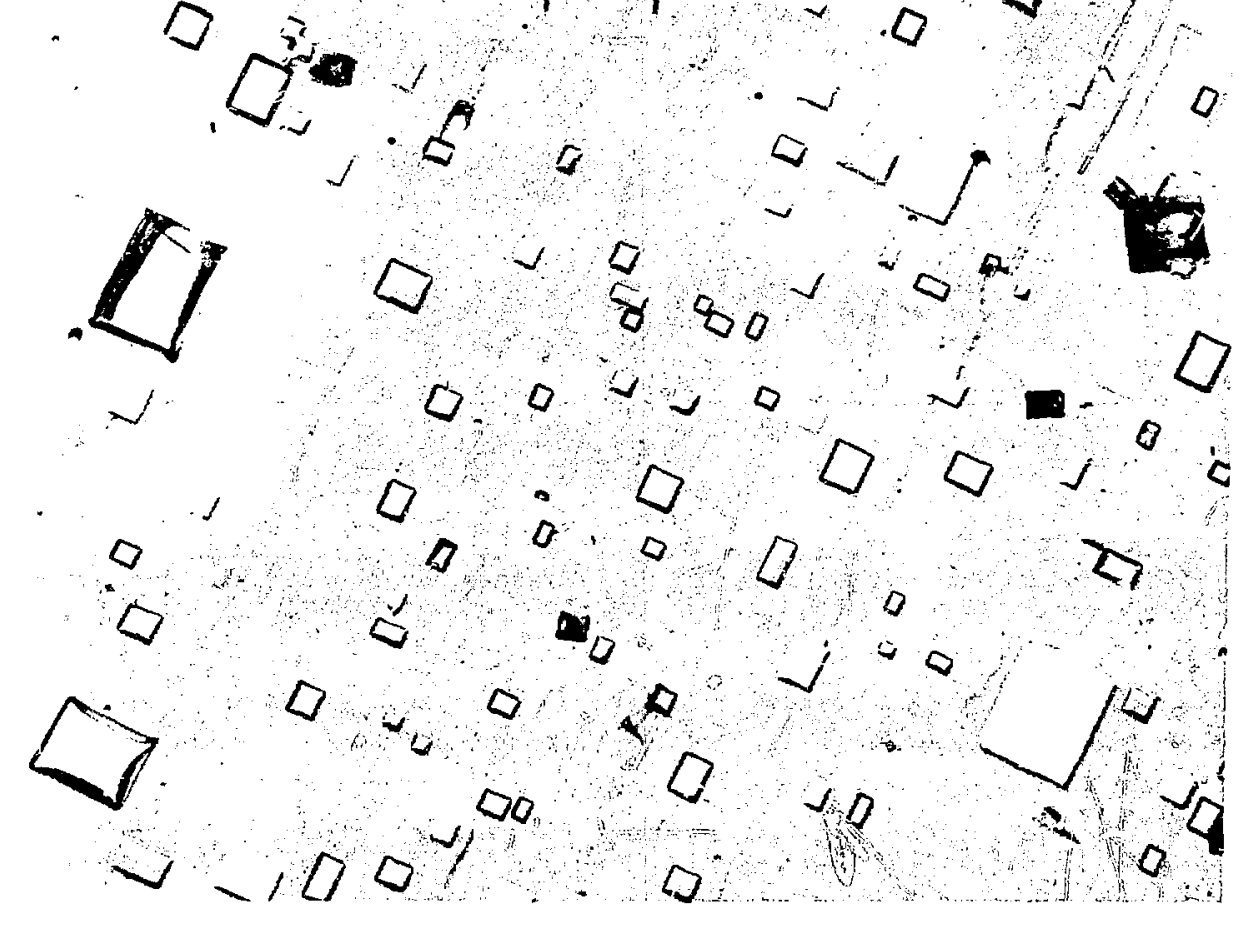

Fig. 2. Electron microscope photograph of a carbon replica of sar-r: B7-5, innealtd. 


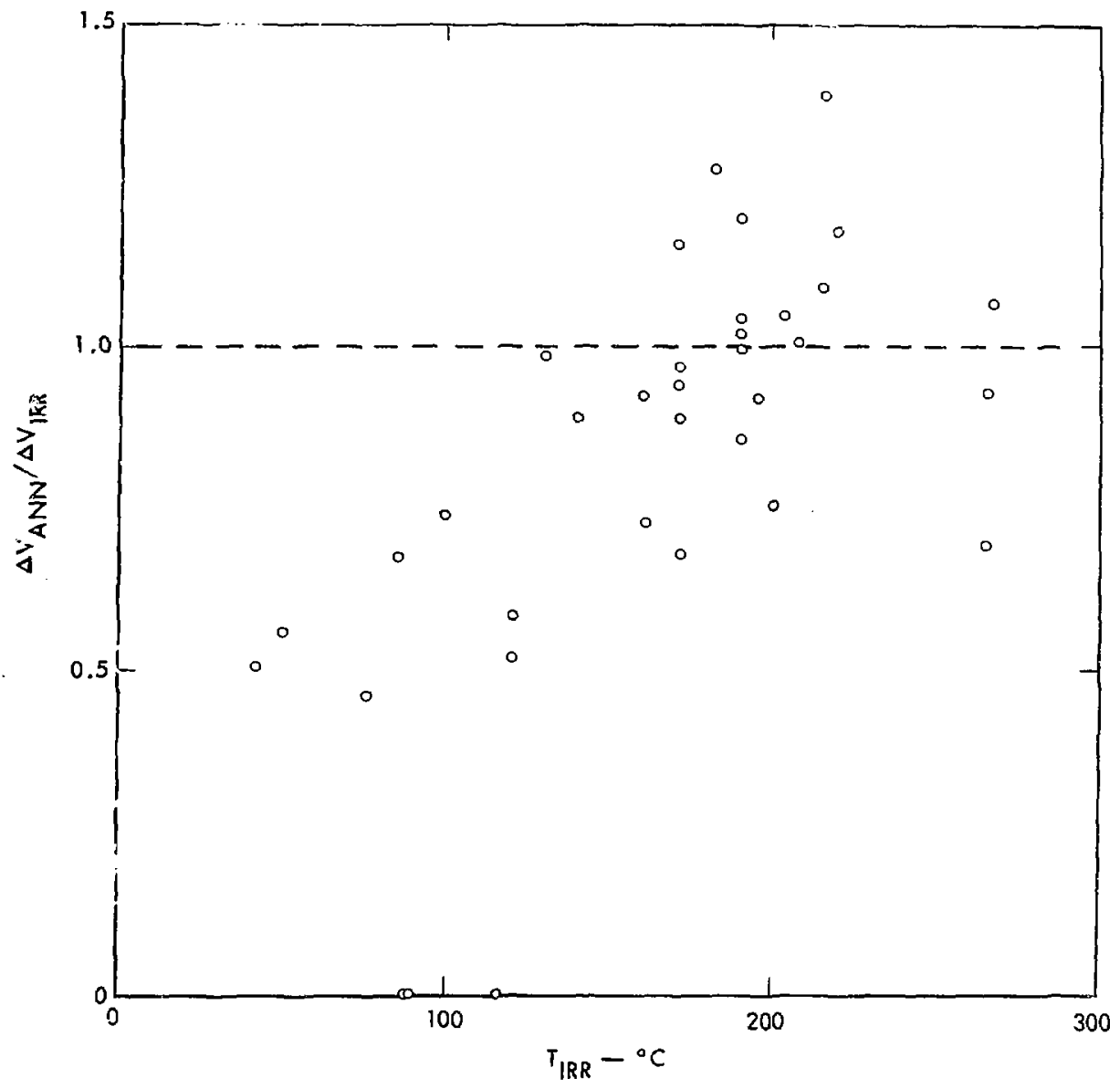

Fig. 3. Relative recovery of swelling of thermally annealed LiH as a function of irradiation temperature. $\triangle V_{I R R}$ is the increase in volume $/ \mathrm{cm}^{3}$ after irradiation. $\Delta \mathrm{V}_{\mathrm{ANN}}$ is the remaining volume increase $/ \mathrm{cm}^{3}$ after anjealing.

aga'nst irradiation temperature for both as-irradiated and annealed samples. The bubble concentration, $\rho$, is defined as ${ }^{2}$

$$
\rho=\frac{\Delta V}{(1+\Delta V)(\bar{r})^{3}} .
$$

where

$$
\begin{aligned}
\Delta V & =\text { swelling volume, and } \\
\overline{\mathbf{r}} & =\text { average bubble size. }
\end{aligned}
$$

It appears that, except for $F$, all annealed samples have approximately the same bubble concentration independent of irradiation conditions or the as-irradiated properties. Since these materials have a considerable range of swelling volume and bubble size, obviously some other property is determining this behavior. If energy minimization is involved, then we 


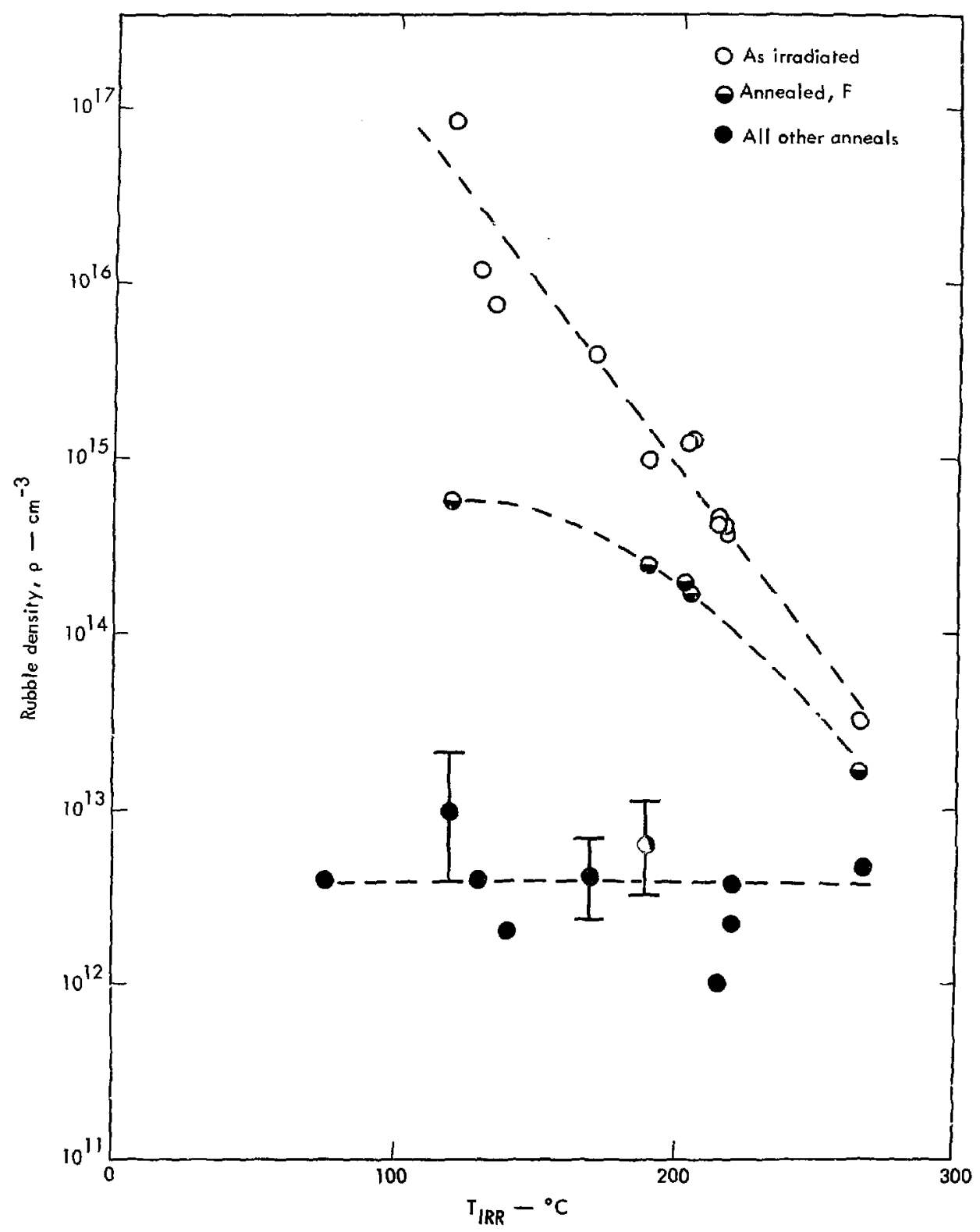

Fig. 4. Bubble concentration as a function of irradiation temperature for as-irradiated and annealed LiH. 


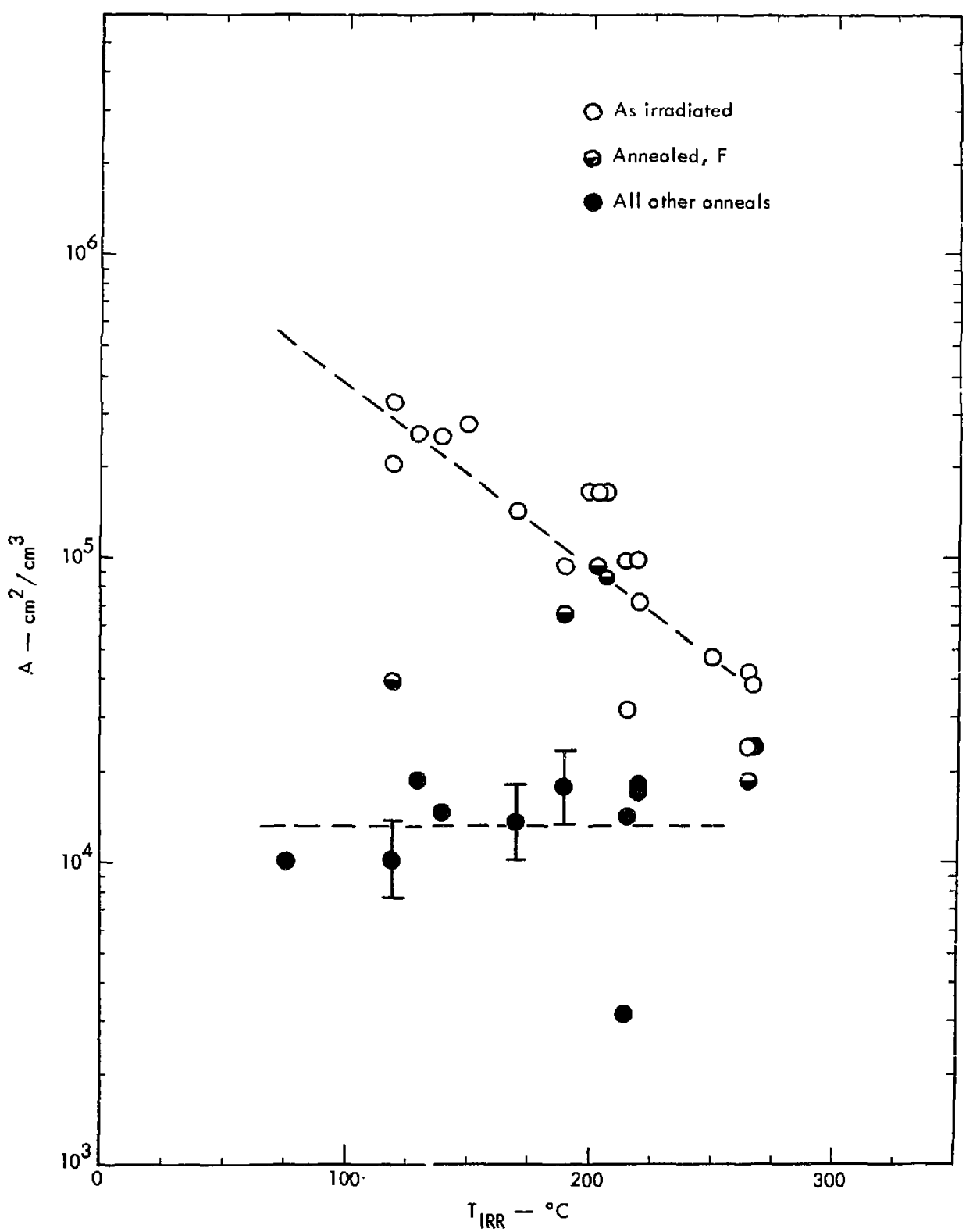

Fig. 5. Internal surface area per $\mathrm{cm}^{3}$ associated with bubbles shown as a function of irradiation temperature for as-irradiated and annealed samples. 
should consider the internal surface area of the bubbles becaus $i$ of their associated surface energy. If this area is defined as

$$
A=6(\bar{r})^{2} \rho=\frac{6 \Delta V}{(1+\Delta V) \bar{r}}
$$

we find that this, too, is constant for annealed materials (except those annealed F). This is shown in Fig. 5 where it can be seen that the annealed materials have a specific internal surface area of $1-2 \times 10^{4} \mathrm{~cm}^{2} / \mathrm{cm}^{3}$. The significance of this $i$, not clear since the minimum energy condition is for zero internal area. In the annealed state, the bubbles are actually voids since the hydrogen has ali back-reacted and there is no balance between internal pressure and surface energy to determine bubble size. It happens that the surface energy calculated from the bubble size and gas pressure is not a constant, as noted earlier. ${ }^{5}$ Apparently equilibrium between surface energy and internal pressure is not achieved, according to the expression

$$
P=4 \gamma / r
$$

where $P$ is pressure, $r$ is bubble size, and $\gamma$ is surface energy. We have plotted $P$ versus $\bar{r}$ in Fig. 6 together with the expected relationship for two values of $\gamma$ and the lack of agreement is obvious. The

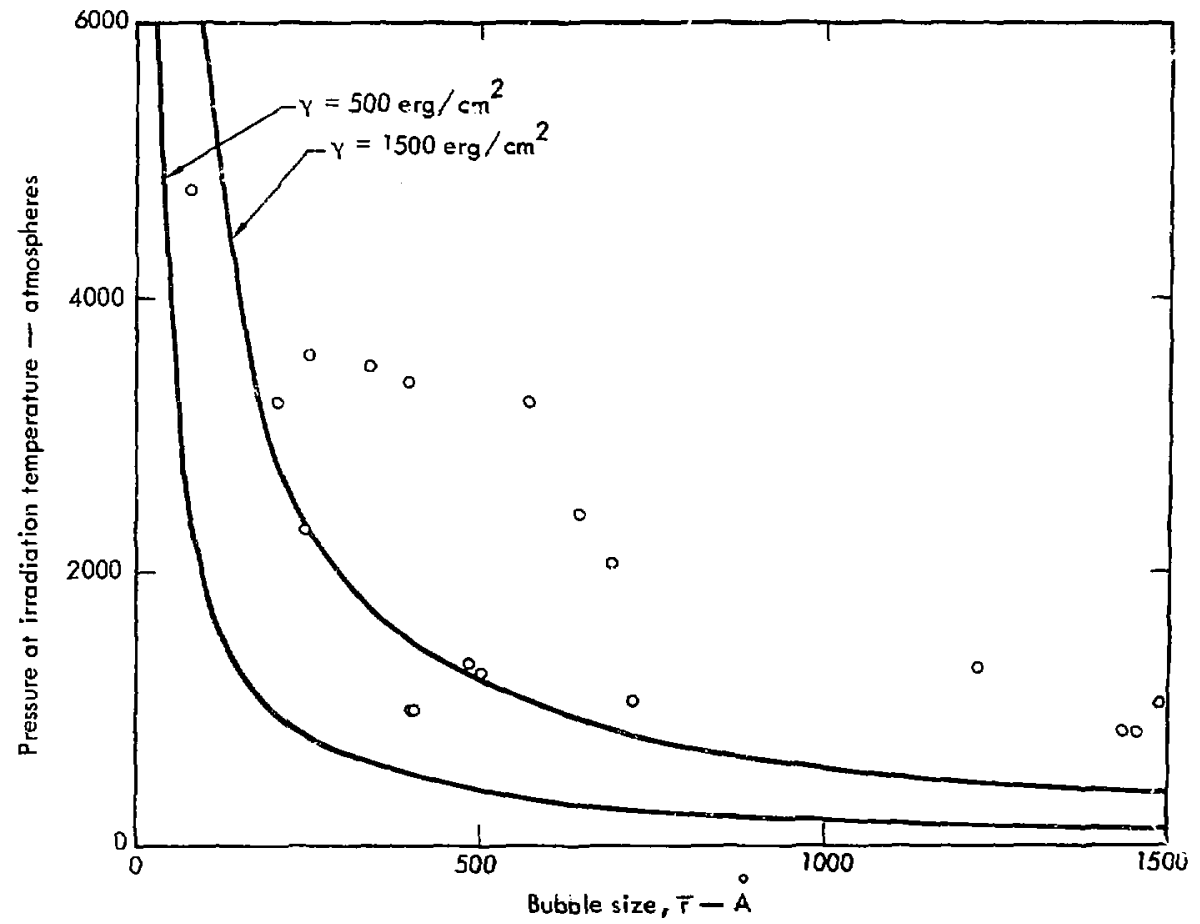

Fig. 6. A comparison of the observed pressure-bubble size relationship with that expected for equilibrium, with surface energy.

$$
\mathbf{P}=\frac{4 \gamma}{r}
$$



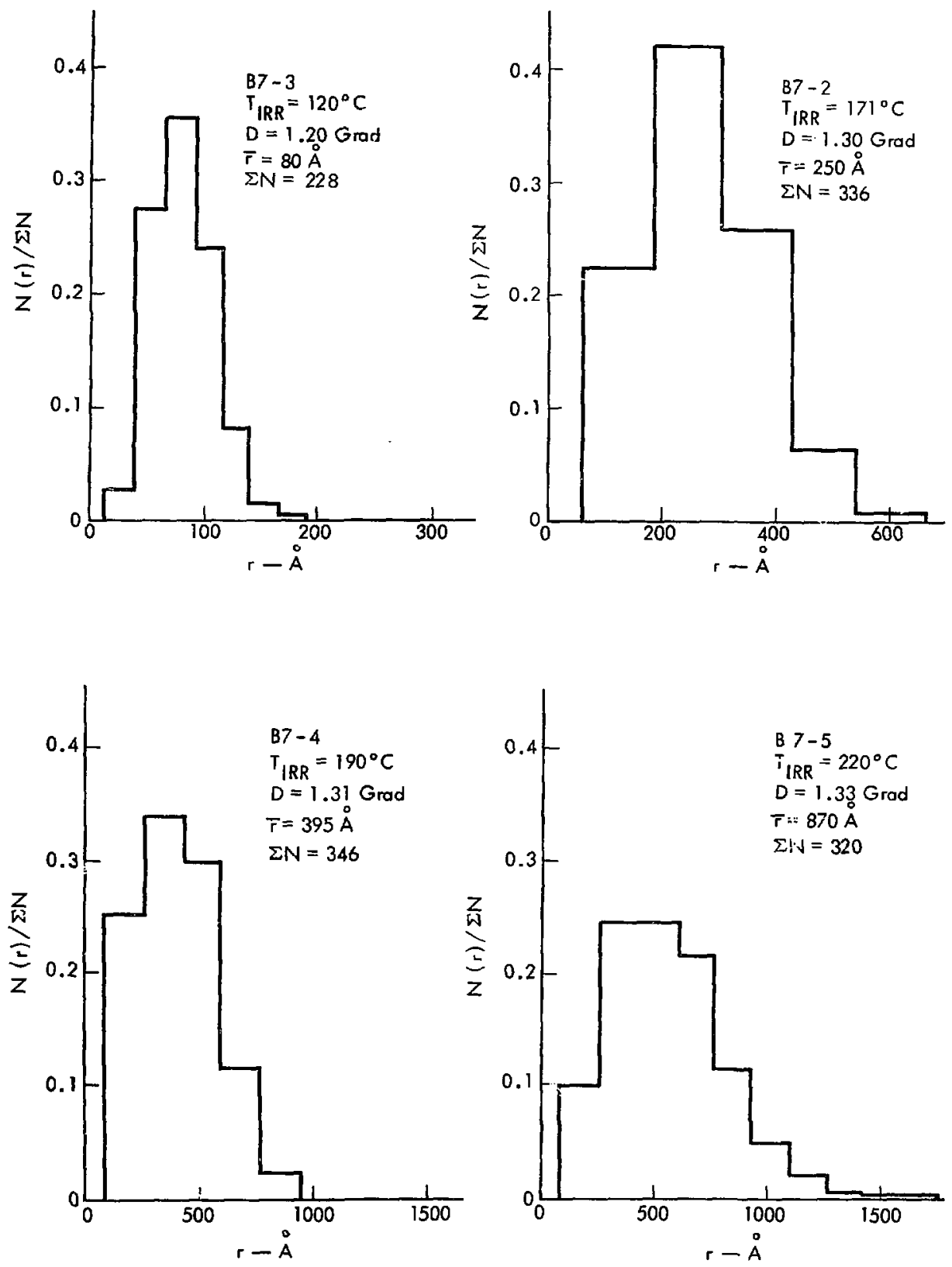

Fig. 7. Distribution of bubbles as a function of size in the as-irradiated B7 series. The fraction of the total is plotted as a function of size. 

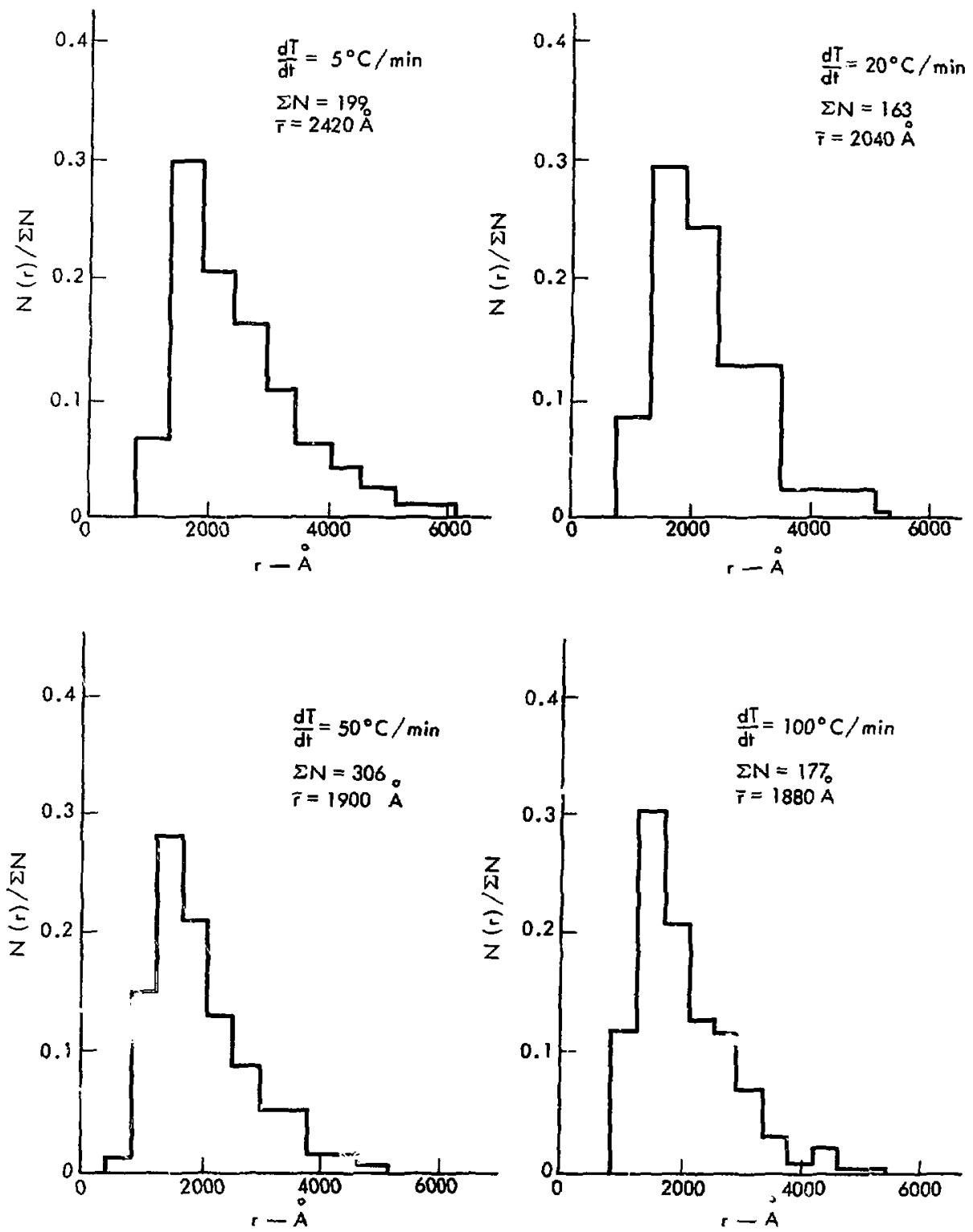

Fig. 8. Bubble size distribution of annealed B7-2 for four constant heating rates. 
value of $\gamma$ for $\mathrm{LiH}$ is expected to be in the range of $250-500$ ergs $/ \mathrm{cm}^{2} .5$

The distribution of bubble sizes in asirradiated and in annealed samples was also examined. The $B-7$ series of samples was studied most extensively because the quality of replicas was generally good for these materials and because more material was available than for other samples. Figure 7 shows the bubble size distribution found in the as-irradiated B-7 samples, and the distributions for sample B-7-2 annealed at four constant heating rates are plotted in Fig. 8 . A distinct difference is found in the type of size distribution between as-irradiated and annealed materials when the cumulative fraction of bubbles sizes is plotted versus normalized size, Fig. 9. The as-irradiated distributions are shown as the open circles and the distributions for annealed samples are shown as full circles. Materials annealed under all conditions are included. It is clear that after annealing, the bubble size distribution is truncated at smaller sizes compared to the as-irradiated condition. For completeness, the individual bubble size populations for all asirradiated and annealed materials not already shown are included in Figs, 10-16. The irradiation conditions and annealing procedures for these are listed in Table 1. The resolution in size distribution was determined by the number and quality of the available electron micrographs.

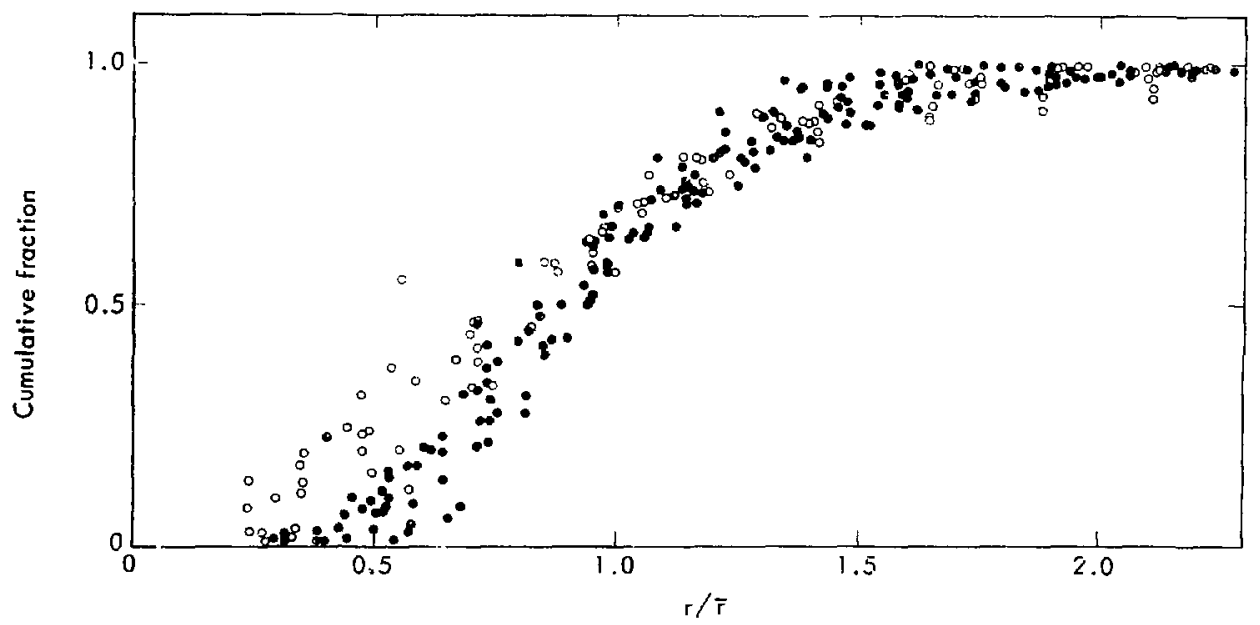

Fig. 9. Cumulative fraction of bubble sizes plotted against bubble size normalized to the average size. Open circles are for as-irradiated samples; filled circles are for annealed samples. 

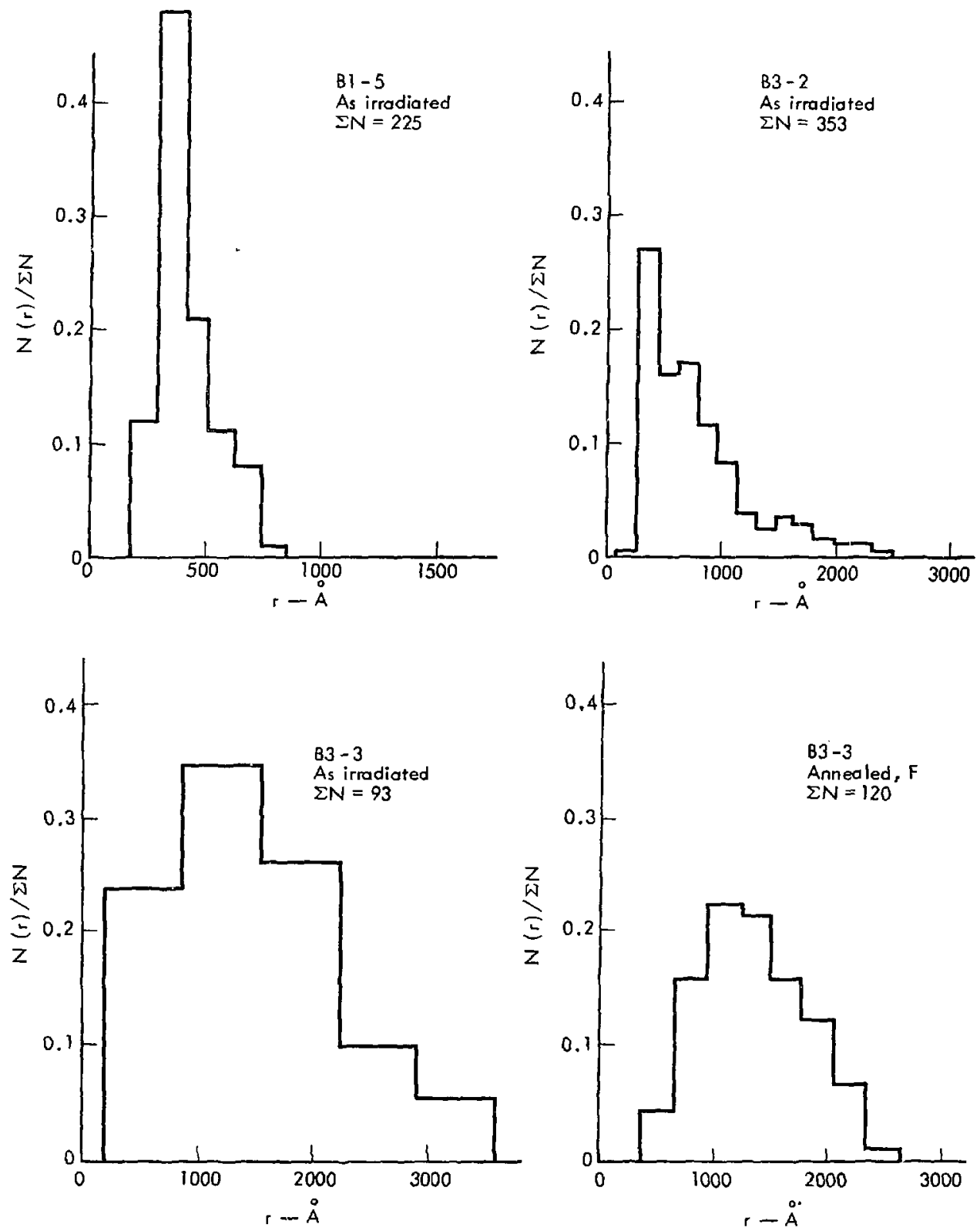

Fig. 10. Bubble distribution for as-irradiated and annealed samples. Fractional population is plotted versus size. 

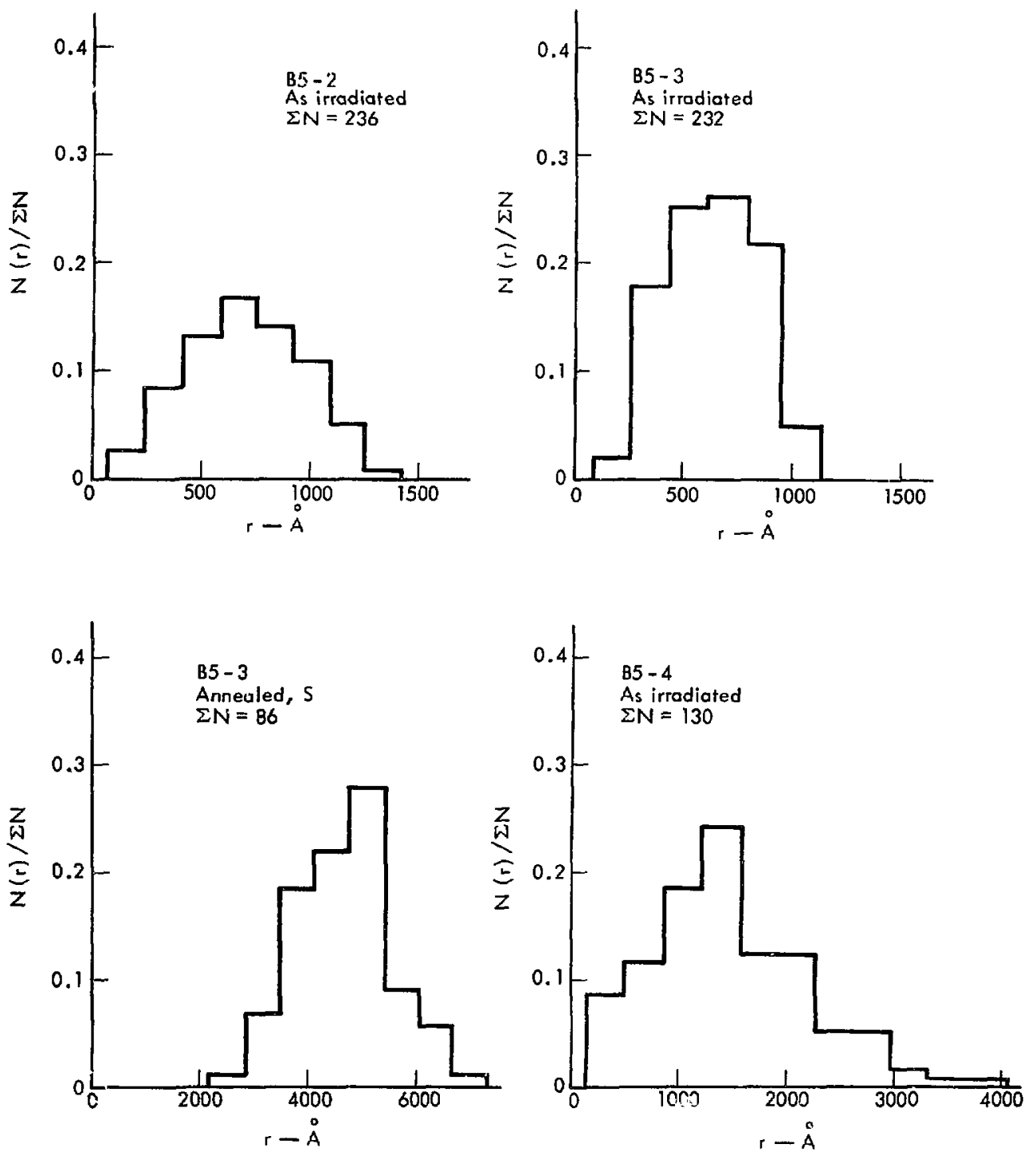

Fig. 11. Bubble distribution for as-irradiated and annealed samples. Fractional population is plotted versus size. 

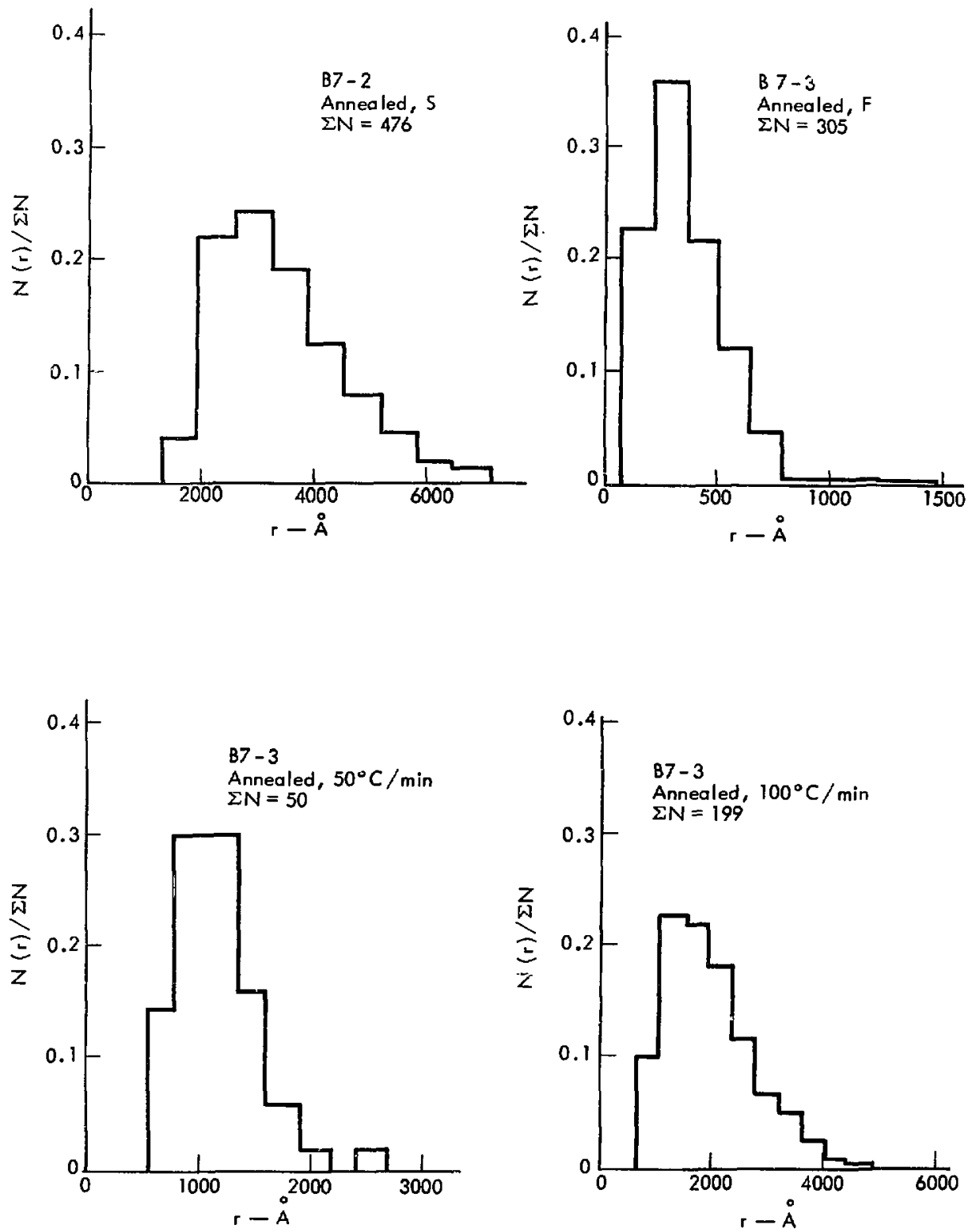

Fig. 12. Bubble distribution for as-irradiated and annealed samples. Fractional population is plotted versus size. 

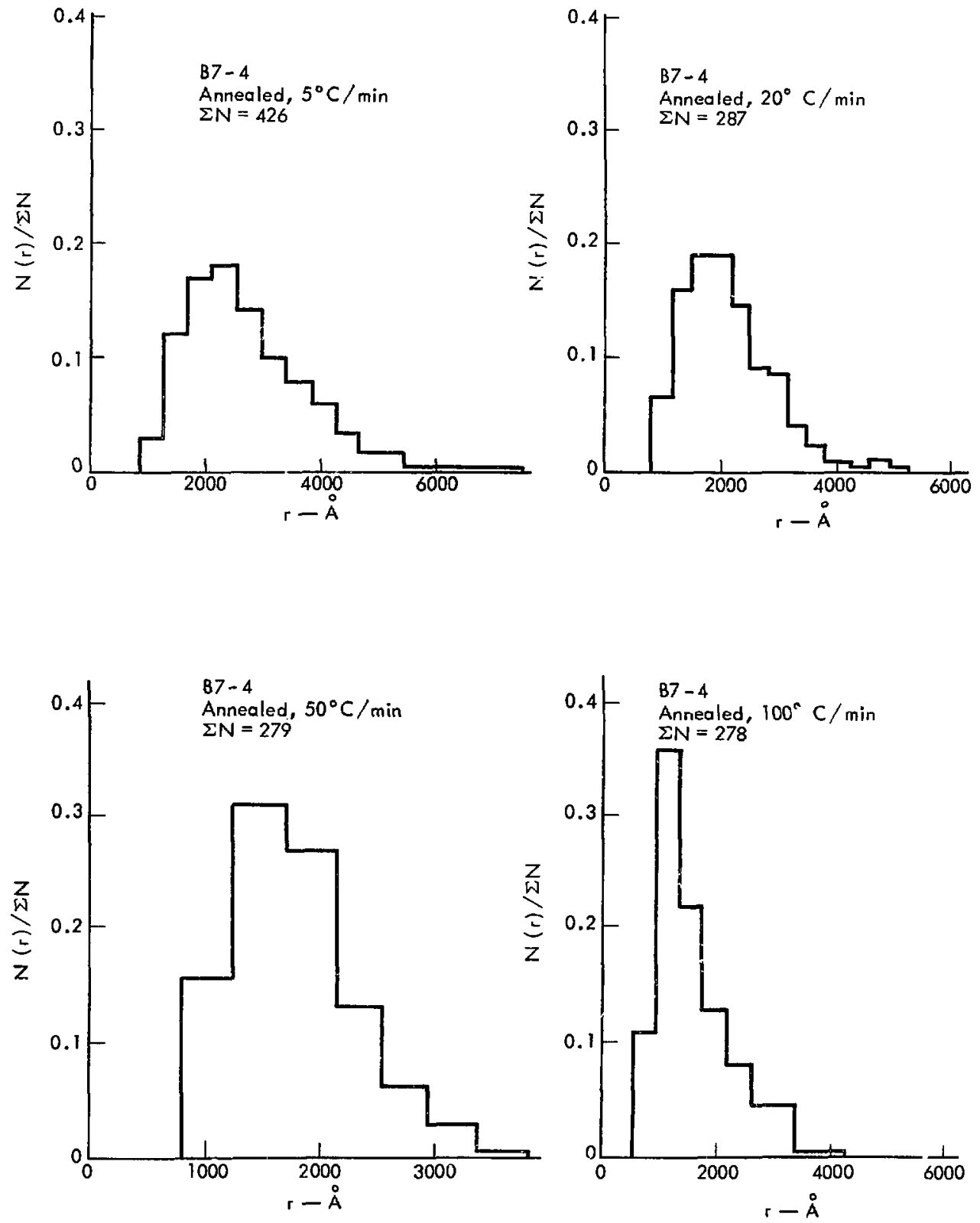

Fig. 13. Bubble distribution for as-irradiated and annealed samples. Fractional population is plotted versus size. 

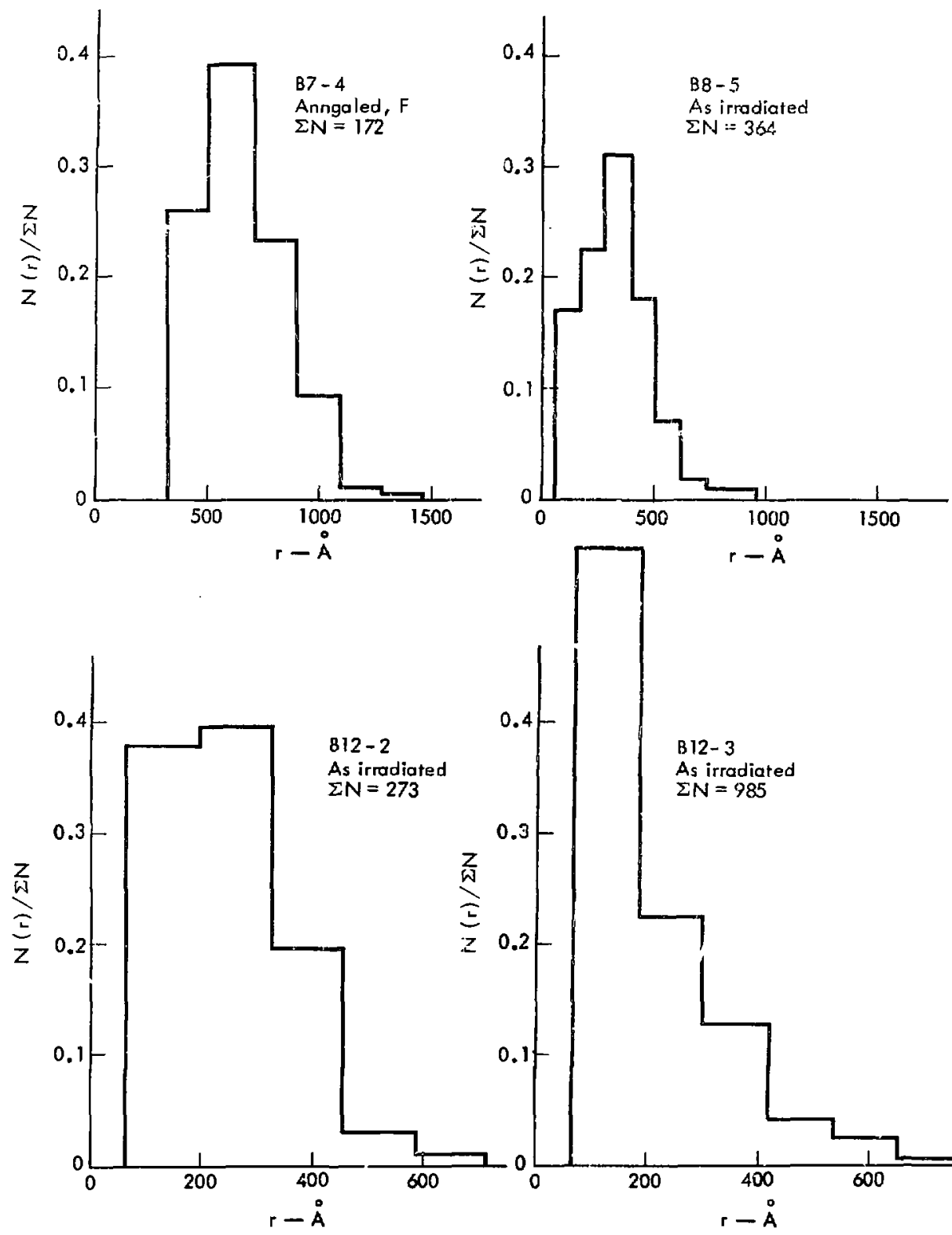

B 12- 3

As irradiated

$\Sigma N=985$

Fig. 14. Bubble distribution for as-irradiated and annealcd samples. Fractional population is plotted versus size. 

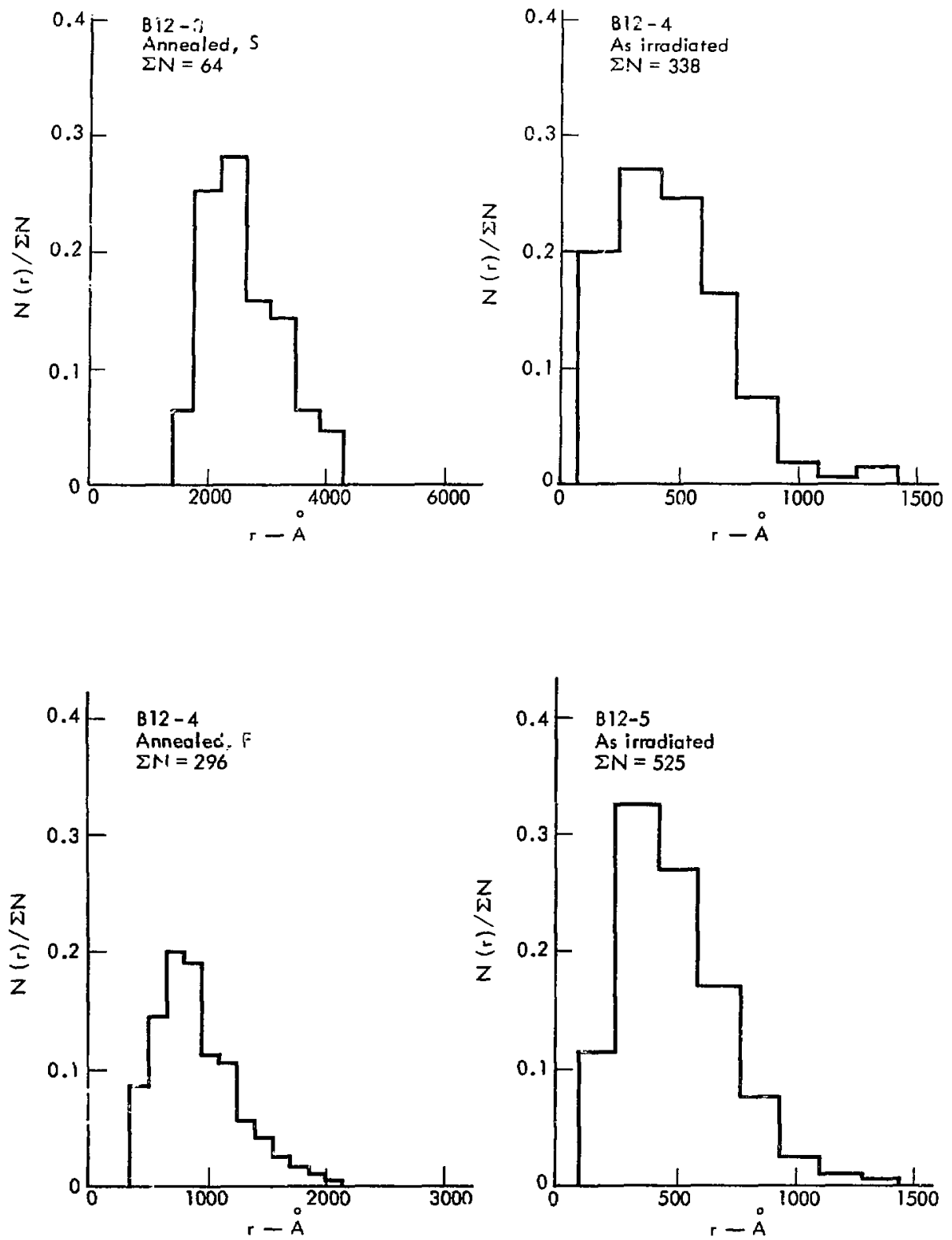

Fig. 15. Bubble distribution for as-irradiated and annealed samples. Fractional population is plotted versus $s i z=$. 

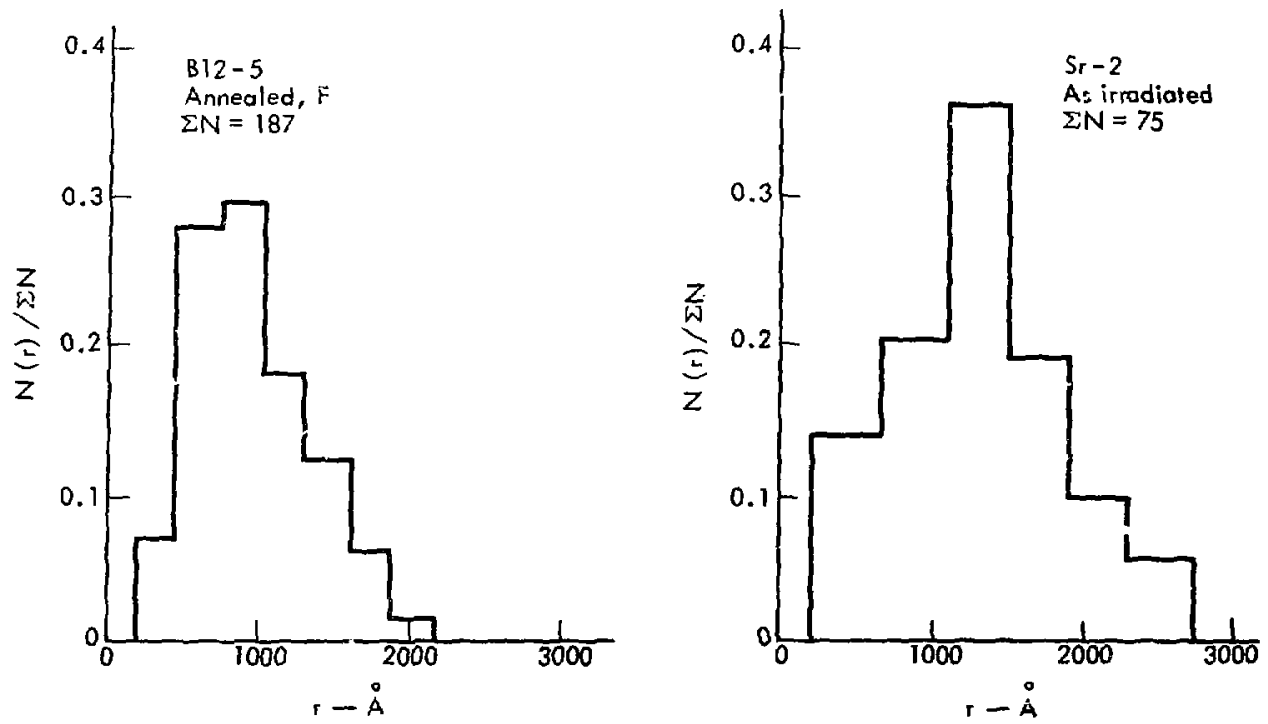

Fig. 16. Bubble distribution for as-irradiated and annealed samples. Fractional population is plotted versus size.

\section{Acknowledgments}

We owe particular thanks to Sam

DiGiallonardo for help with the replication

procedure and for providing us with many superior electron micrographs. We also wish to thank P. C. Souers, T. S. Blake, and $T$. Imai, who ali participated in the early stages of these experiments. 


\section{References}

1. H. W, Newkirk and H, R. Leider, J. Phys. Chem. Solids 31, 106ভ (1970).

2. H. R. Leider, J. Phys. Chem. Solids 31, 1221 (1970).

3. P. C. Souers, T. S. Blake, R. M. Penpraze, and H. R. Leider, Further Studies on Irradiated Lithium Hydride: Metal Formation and Thermal Annealing Behavior, Lawrence Livermore Laboratory, Rept. UCRL-50726 (1969).

4. T. Imai, Phil. Mag. 21, 281 (1970).

5. P. C. Souers, T. Imai, T. S. Blake, R. M. Penpraze and H. R. Leider, J. Phys. Chem. Solids 31,1461 (1970).

6. P. C. Souers, T. S. Blake, R. M. Penpraze and C. F. Cline, J. Phys. Chem. Solids $\underline{30}, 2649$ (1969). 